\title{
O belo nas poesias de Carlos Drummond na perspectiva filosófica de Benedito Nunes
}

\author{
The beautiful in the poetry of Carlos Drummond in the \\ philosophical perspective of Benedito Nunes
}

\author{
José Roberto Nunes \\ https://orcid.org/0000-0002-7114-6627 -E-mail: robertogomes@ufam.edu.br \\ Michele Menezes da Silva \\ https://orcid.org/0000-0002-2213-4371 - E-mail: silvamm372@gmail.com
}

\begin{abstract}
RESUMO
Este artigo tem como objetivo principal compreender em que consiste o belo na poesia pela perspectiva filosófica de Benedito Nunes a partir dos poemas de Carlos Drummond de Andrade. Especificamente faremos o percurso que fizeram alguns filósofos na sua discussão sobre o que é o belo para em seguida demonstrar como o pensamento de Heidegger influenciou o modo de pensar filosófico de Benedito Nunes e por fim demonstrar como a poesia expressa o mundo sensível pelos poemas de Carlos Drummond de Andrade, percebendo a relação com os aspectos filosóficos e literários e de como o Belo se configura nesse contexto. Para o alcance dos objetivos optamos em realizar uma pesquisa descritiva e bibliográfica, seguindo o percurso teórico de Benedito Nunes, a partir da obra Crivo de Papel (1998). A pesquisa dialoga com duas grandes áreas humanas Filosofia e Literatura estão interligadas ao falarmos sobre a poesia, e de como o Belo como está presente de forma particular na nossa experiência sensível.
\end{abstract}

Palavras-chave: Belo. Poesia. Filosofia. Carlos Drummond. Benedito Nunes.

\begin{abstract}
The main objective of this article is to understand what is beautiful in poetry from the philosophical perspective of Benedito Nunes based on the poems of Carlos Drummond de Andrade.
\end{abstract}


Specifically, we will take the path that some philosophers made in their discussion of what is beautiful, and then demonstrate how Heidegger's thought influenced Benedito Nunes 'philosophical way of thinking and finally demonstrate how poetry expresses the sensitive world by Carlos' poems. Drummond de Andrade, realizing the relationship with the philosophical and literary aspects and how Belo is configured in this context. To achieve the objectives, we opted to carry out a descriptive and bibliographic research, following the theoretical path of Benedito Nunes, from the work Crivo de Papel (1998). The research dialogues with two major human areas Philosophy and Literature are interconnected when we talk about poetry, and how the Beautiful as it is present in a particular way in our sensitive experience.

Keywords: Belo. Poetry. Philosophy. Carlos Drummond. Benedito Nunes.

\section{Articulações entre o pensamento de Heidegger e Benedito Nunes}

Neste tópico pretendemos discutir sobre a influência do pensamento de Heidegger em Benedito Nunes no que tange a compreensão do belo. A filosofia de Heidegger é a filosofia sobre o sentido do ser. Nesse sentido, Nunes tenta discutir e refletir os dois elementos, arte e poesia a partir da perspectiva de Heidegger sobre o sentido do ser.

Como hermenêutica, a filosofia de Heidegger, na medida em que tomou para seu tema a questão do sentido do ser [...]. O exame desse problema constitui a meu ver, o indispensável prólogo à leitura de "A origem da obra de arte", escrito heideggeriano [...] que centraliza esta minha tentativa de reflexão sobre a experiência pensante da arte e da poesia nesse filósofo (NUNES, 1998, p. 89).

Heidegger considera que a questão mais relevante da Filosofia é a busca pelo sentido do ser. Heidegger faz a escolha pela arte como aquela que guarda em si o segredo sobre o ser. Na obra de arte temos acesso marginal ao ser, pois o ente é obra de arte que vela a Arte (o ser). Nesse sentido, a poesia é a ao mesmo tempo ente que não se determina por uma essência prévia à maneira de um objeto como também é aquele que revela o ser, isto é, a poesia é projeto do ser. Se partimos deste teor da verdade em sua completude, acabaremos descobrindo o seu sentido poético, ou seja, na poesia apesar de vir questões que vislumbrem a realidade, há também questões das estruturas que desvelam o ser.

A partir desse direcionamento Heidegger pensa a obra de arte como algo que nasce do sensível que não está no objetivável ou no visto. Por meio dela revela-se o cotidiano, e essa revelação acontece por meio de uma compreensão poética de como se ver o mundo. O que importa é uma primeira abertura da vista para o fato de o caráter de coisa da coisa só se aproximarem de nós se pensarmos o ser do ente. Para isso é necessário que primeiramente caiam as barreiras dos ilusórios conceitos correntes. Para Heidegger que o originário está na obra de arte e no artista porque na obra da arte a verdade do ente se pôs em obra. Desse modo, essência da arte seria pôr-se-em-obra da verdade do ente. Afirma Nunes em sua leitura sobre Heidegger:

Em A Origem da Obra de Arte, podemos perceber que a preocupação inicial de Heidegger está relacionada ao originário, que ele diz ser aquilo a partir do que é algo é o que ele é e como ele é, ou seja, o originário provém da essência. Então se o originário é através da essência, onde está essência e originário quando nos referimos a arte? Na própria obra de arte ou no artista (NUNES, 2014, p. 12).

Ambos são origem um do outro, arte e artista. Um depende do outro. E nessa busca da essência da arte, o filósofo ver a obra de arte como coisa, ou seja, ela é natural. Num processo 
de coisificação é que a essência se encontra, por isso a dependência para se existir obra de arte e artista. Logo, esses dois são dependentes para se obter a essência. Dessa forma, "a essência da obra de arte não reside nem na sua criação pelo artista nem no ato de contemplá-la, e sim na sua origem - no ser mesmo que se desvela na obra, que assoma em sua organização sensível, ôntica [...]" (NUNES, 2000, p. 111).

Para Benedito Nunes, Heidegger pensa a arte como o poético, irrupção do ente que faz a verdade acontecer, abrindo espaço de sua aparição a partir da terra que se desvela, antecede a ideia e a possibilidade (NUNES, 1998, p. 103). Que terra se desvela, antecede a ideia e a possibilidade? Terra é o mundo em que se instala o ser da obra. Mas o que é isto, um mundo? Aonde a obra se recolhe e o que deixa vir à luz nesse recolher-se, a isso podemos chamar mundo. $\mathrm{Na}$ medida em que a obra instala um mundo, elabora a terra. A pedra, a rocha, as plantas, o homem, a mulher são elementos que na obra fundam um sentido do ser na medida em que a obra instala um mundo, elabora a terra. O elaborar é aqui para ser pensado no sentido estrito da palavra. Por certo o poeta usa a palavra, mas não como o falante e escrevinhador habituais usam as palavras, e sim de tal forma que a palavra se torna pela primeira vez verdadeiramente uma palavra e assim permanece.

Nesse sentido, ao tomarmos o pensamento de Heidegger sobre a poesia, coloca-se em discussão a linguagem, já que para ele a linguagem tem um papel fundamental. Adentrando nessa questão, pensemos sobre a essência da verdade. Para Heidegger tal essência está por detrás do enunciado e nunca nele, logo, podemos pensar que mais detrás ainda se encontra a não-verdade. É a reflexão que direciona o pensamento sobre determinada essência; assim para se concretizar essa reflexão entram como ferramentas a linguagem e a poesia. São elas que vão esclarecer que a verdade é algo muito mais profundo, é a base concretizadora do homem na terra, do ser no mundo, o Dasein ${ }^{1}$.

Sob esse foco, a compreensão do ser, manifesta em tudo quanto pensamos, enunciamos, expressamos ou fazemos, é o que distingue o homem como Dasein, isto é, como aquele ente que existe compreendendo o ser, e que pode, por isso, interpretar de uma certa maneira a si mesmo e ao mundo, co-assumido nessa compreensão (NUNES, 1998, p. 91).

Os elementos fundamentais para o desenvolvimento do Dasein, para abertura do ser-no-mundo, são a disposição e a compreensão. A linguagem vem em seguida como modo com o que o Dasein usa para mostrar o que é compreendido sobre seu envolvimento com o mundo. A função da linguagem é a de expressar o que é articulado no discurso e na interpretação, ela é composta por um conjunto de símbolos e é um fenômeno posterior à analítica existencial; o Dasein abre-se para a linguagem pelo ato do discurso.

Dentro desse contexto, a poesia é a ferramenta utilizada pelo poeta e que deve vir à tona. Não pode ser vista simplesmente como atividade de criação e como questionamento ou reflexão sobre determinado contexto. É por meio do poeta que a poesia ganha uniformidade, que ela se funda; e, esse ato fundador tem consistência. Não é criado sem fundamentos, pois a poesia é fundação que ocorre na palavra, pela palavra e é nela que o poeta tem o seu maior bem para exprimir seu contato originário com o sensível. Portanto, o ato do discurso que se materializa na palavra faz suscitar a essência do poeta, a poiesis.

Heidegger tem precisamente na linguagem poética o lugar privilegiado da manifestação do ser. Heidegger vê na obra de Hölderlin um impulso de compreensão que se traduz

\footnotetext{
1 Termo heideggeriano que se traduz por ser-aí. Significa presença em meio aos entes. O Dasein é o único ente a possuir sentido, o único capaz de criar, desejar, construir que se põe em relação com os demais entes.
} 
pela poesia em instrumento que prepara o homem, que ensina quem ele é, não se deixando levar ou se convencer com qualquer discurso. Logo, a linguagem poética torna possível a abertura para a compreensão do Dasein porque exprime a existência em sua naturalidade própria, isto é, antes que haja o poema há o fazer poesia como atividade criadora.

Nessa perspectiva,"o acontecimento da arte enquanto poesia, e a poesia enquanto instauração da verdade, fornecem-nos o quadro compreensivo dos estudos sobre Hölderlin [...]" (NUNES, 2000, p. 112).

Mas a palavra poética não delega a verdade ao Dasein. É ao próprio ser, culto ou revelado através dela, que a verdade pertence. Se o Dasein está na verdade, ele o está como aquele que ocupa a abertura na direção da qual se move. O que, finalmente, Heidegger aprende de Hölderlin é a finitude do homem como Dasein, sujeito aos poderes contraditórios da linguagem: jogo inocente com as palavras, o exercício da poesia é a mais perigosa das ocupações, porque, mexendo com a linguagem, mexe com a abertura e seu velamento, com a verdade e a não verdade (NUNES, 2000, p. 117).

A característica principal da poesia de Hölderlin é seu horizonte amplo em que se estabelece toda determinação humana. A essência de sua poesia nunca se define por uma mera determinação real, uma simples definição ou descrição, ela na verdade se impõe como acontecimento fundamentado no ser. Não há a descaracterização da sua essência mais ocultação que é o mistério que se desvela pelas palavras. De acordo com Heidegger, para Hölderlin a poesia enseja a habitação dos homens, pois Ihes permite habitar poeticamente a terra.

Por tal motivo, é a fundação (das Stiften) aquilo que se mantém próximo da origem, aquilo que permanece, porque a fundação, como caminhada pudica/temerosa à nascente, apenas dificilmente pode abandonar o lugar da proximidade. O que este fundar funda enquanto permanecer que indica, pois, é ele mesmo. O permanecer é aqui o permanente. O poeta pode chamar o"fundado" de um permanente. Apenas este fundado é aquilo que ele pensa tal como é, a saber, "o que fica" (HEIDEGGER, 2002, p. 167).

A obra de arte assim como a poesia, essa caracterizada a partir do Hölderlin, amplia o horizonte de reflexão, fugindo da mera determinação real, daquilo que está na palavra, na superficialidade, mas atua como interrupção, ou seja, naquilo que está por detrás da palavra, nos intermédios dos discursos.

Cada poeta permanece então por si mesmo aberto dentro do aberto, que se ilumina do "alto Éter até o fundo do abismo". A abertura do aberto conforma-se àquilo que chamamos de "um mundo". Apenas por isso, conforme esses poetas, os sinais e as ações do mundo entram na luz; pois os poetas não são carentes de mundo. Conquanto os poetas, segundo a sua essência, pertençam ao sagrado, e sejam inspirados ao pensarem o espírito, isto é, a realidade de todo o real, devem eles ao mesmo tempo ser admitidos ao real e ali ficar presos (HEIDEGGER, 2002, p. 170).

Desse modo, Heidegger coloca a poesia e a filosofia numa relação recíproca. Apropriando-se desse pensamento, Benedito Nunes fala da interação entre filosofia e poesia ao falarmos de sua essência e de seu poder de expressividade, ou seja, ambas carregam teores de reflexão e questionamentos diante de determinadas temáticas, contextos e espaços. A poesia dialoga filosoficamente, assim como a filosofia dialoga poeticamente em um: "[...] movimento de vai e vem, ora da poesia para a filosofia ora da filosofia para a poesia" (NUNES, 2000, p. 105).

Ao tratar da arte, ou particularmente da literatura e da poesia, o filósofo já se defrontava com os problemas mais gerais do pensamento - o ato de conhecer, a linguagem, o Eu, a relação entre alma e corpo, o sono e o sonho, a simulação, a sinceridade, as regras morais - que também faziam parte do da experiência do poeta [...] (NUNES, 2000, p. 115). 
Por isso, Benedito Nunes traz para a literatura a filosofia e oferece a esta a literatura como nascedouro para pensar a linguagem. Nesse processo, as experiências do poeta e do filósofo se entrecruzam. Entre essas experiências o espanto torna-se um ponto importante. $O$ espanto não determina de como as coisas devem ser, mas são como são e não diferentes. Logo, como destacado: o conhecimento, a linguagem, o Eu, dentre outros elementos fazem parte das experiências tanto do poeta quanto do filósofo.

No momento em que a imaginação colabora no mecanismo da invenção, tem-se aí um afloramento da poética, incluem-se nela os sábios, não ficando de fora os filósofos. É nesse mecanismo integrante que se encontram presentes "[...] o dos que vão da poética à filosofia e o dos que vão da filosofia à poética" (NUNES, 1998, p. 67).

Ao pensarmos nos dois caminhos que se entrecruzam, também, devemos levar em consideração e destacar a matéria enquanto expressão artística. É justamente a matéria que exprime e ao mesmo tempo solicita as atitudes construtivas de quem tem contato com ela.

A matéria, que solicita a sensibilidade e a imaginação, também convoca o ato de pensamento, como projeto que se transforma em acontecimento: a obra, produto de um fazer inteligível, sendo ela mesma um entendimento ativo, operatório - chamado de forma - consumado num instante de tempo (NUNES, 1998, p. 70).

O poema como obra de arte, por meio do ato do pensamento se transforma em acontecimento, é a solidificação ativa e operatória. Sua materialidade por meio da linguagem é edificada; é através das metáforas trazidas por ela que se tem a ideia do que é belo em um pensamento mais universal e abstrato. Segundo Nunes, Sócrates já antecipou em seus diálogos que a linguagem já secretamente edificaria, pela força de suas metáforas, a ideia de belo universal e abstrato (1998, p. 72).

Há de se considerar a linguagem como elemento de análise de estudo da filosofia. Vários filósofos, tomaram a linguagem como ponto de reflexão filosófica, já que ela é a mediadora da expressão do pensamento. A literatura, não obstante, também toma a linguagem como elemento de expressividade

Nessa perspectiva, se pensarmos historicamente na relação entre filosofia e literatura, elas se destacam na história do pensamento ocidental. Tal relação vem desde os pensadores pré-socráticos até os autores contemporâneos. Quando destacamos especificamente a história da filosofia, vemos dentre os autores da literatura, em meio aos seus textos, produzirem grandes e profundas reflexões filosóficas, dentre esses, Homero, Cícero, Shakespeare dentre outros. Não diferente, temos filósofos que utilizam os recursos literários ao expressarem sua filosofia, como: Platão, Santo Agostinho, Sartre entre outros. Destaca Magalhães: "A relação entre filosofia e literatura pertence à história de ambas em sua especificidade e em alguns momentos ambas confundem-se, pois muitas vezes o pensar filosófico se dá na literatura e a literatura refrata os grandes debates desenvolvidos na filosofia" (2009, p. 47).

A relação entre filosofia e poesia tem em comum o mesmo solo, pois nascem do ser no mundo que coloca nas suas investigações (filosofia) e nas suas descrições (poemas) o que se apresenta no mundo sensível. Filosofar e poetizar são atos criacionais no sentido de poeisis. Por isso, uma disciplina estética não tem como ser ensinada, pois antes que se aprenda sobre ela já estamos nela inseridos pelo mundo sensível que habitamos.

Vê-se, portanto, que o regime normativo da Estética, enquanto disciplina filosófica, apenas externava o fenômeno da subjetivação generalizada, soberana, na apreciação do belo e na produção artística. "A obra de arte é colocada como 'objeto' para um 'sujeito', comenta Heidegger. Essa consideração baseia-se na relação sujeito-objeto, fundamentalmente a relação sensível (NUNES, 1998, p. 99). 
Portanto, nessa relação entre literatura e filosofia, e entre os aspectos que estão presentes nessas duas grandes áreas do conhecimento é que pretendemos realizar a análise dos poemas de Carlos Drummond na perspectiva de Benedito Nunes, com o intuito de perceber como tais aspectos se fazem presente e como eles se articulam dentro da poesia.

\section{0 belo nas poesias de Carlos Drummond de Andrade por Benedito Nunes}

Neste tópico estudaremos três poemas do poeta, cronista e contista Carlos Drummond de Andrade que são tomados por Benedito Nunes em sua obra Crivo de papel, que tem sido a base investigativa orientadora deste artigo. O Crivo de papel segue a lógica de apresentar como filosofia que se une a poesia e vice-versa; assim, como Hördellin através de seus poemas esteve para Heidegger em sua busca de compreensão sobre o belo Drummond está para Benedito Nunes na sua exposição sobre o que é o belo. Embora no Crivo de papel ele tome outros poetas, como Guimarães Rosa, a escolha por Drummond se deve a paralelos que se aproximam mais de Hördellin na forma de composição do poema.

É interessante começar esta análise pelo título da obra: Crivo de papel. Crivo significa crítica ou prova, avaliação detalhada sobre algo ou alguém que não passou por uma avaliação e ainda pode ser peneira de fio metálico para separar fio metálico, de arame utilizada para separar pedras, migalhas e pedras preciosas. Detendo-nos nessas significações sobre crivo já conseguimos perceber o sentido empregado por Benedito Nunes. Através de um cuidadoso trabalho crítico-avaliativo se passa por uma peneira de papel a busca de Benedito Nunes em reavaliar no decorrer da história literária qual o sentido do Belo na Arte e para isso transita desde Platão passando por Aristóteles, Hegel, Kant, Valéry para chegar em Heidegger, a quem toma como aquele que conseguiu captar de melhor o sentido iniciado pelos anteriores na compreensão do belo. Ainda é interessante que o crivo é de papel e não de metal, pois as palavras expostas ao longo do tempo pelos mais diversos poetas e filósofos são como peneiradas para ficar no crivo apenas as migalhas ou pedras preciosas. Mas quê migalhas? Quê pedras preciosas?

Carlos Drummond de Andrade se situa no período modernista e é considerado um dos maiores escritores brasileiros. Os poemas a serem analisados são $O$ sobrevivente e Explicação, ambos contidos na obra Alguma poesia (2013); e Passagem da noite na obra A rosa do povo (2012). Nesse sentido, nosso objetivo é analisá-las em duas perspectivas: literária e filosófica de modo a buscar o belo nesses dois textos. Embora no Crivo de papel estejam apenas recortes dos poemas optamos por trazê-los na íntegra e fazer apontamentos sobre alguns trechos no sentido de alargar a reflexão de Benedito Nunes.

O primeiro poema a ser analisado é $O$ sobrevivente. Construído com aspectos lírico, de insatisfação, de incômodo, de sarcasmo, de ironia, todos trabalhados com o cuidado de preservar o belo poético e a reflexão literária e filosófica.

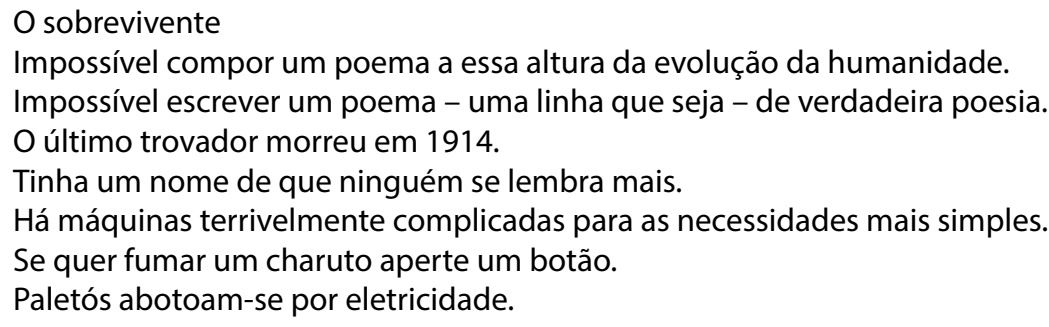




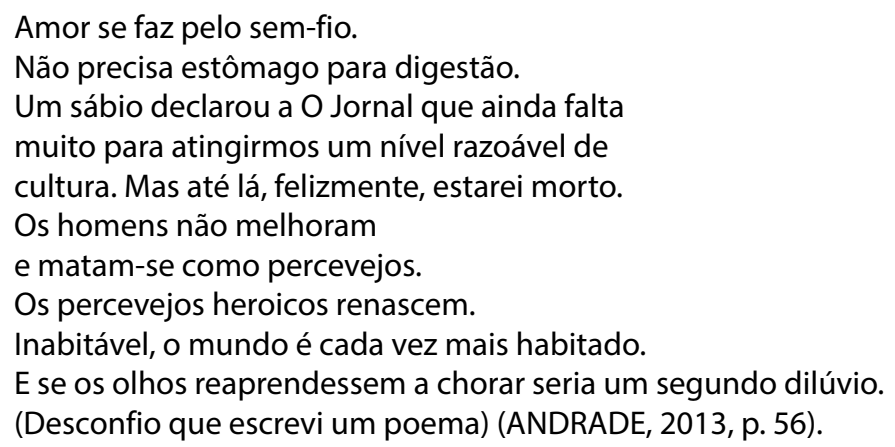

Percebemos que o poema de Drummond, apresenta uma multiplicidade de temas e se constrói numa expressividade muito rica. Procura mergulhar de forma profunda no campo da condição humana, pelo título do poema já observamos tal expressividade de condição $O$ sobrevivente. O título nos condiciona a pensar, a refletir de algo ou alguém que sobreviveu sobre determinada situação, momento ou condição, mesmo sem nos direcionarmos ainda para o texto integral do poema. Para o poeta se sobrevive e não se vive. Aí temos um aspecto filosófico importante, o impulsionado do pensar que nos direciona a perceber aquilo que está além mesmo que não esteja explícito e ao mesmo tempo nos leva a olhar para o que é sobreviver.

Pensando o poema há nele uma crítica direta a substituição dos elementos do cotidiano por algo cujo contato direto com o objeto não se tem mais, como se observa no fragmento "há máquinas terrivelmente complicadas para as necessidades mais simples". Atualmente o ser humano se apegou às máquinas para suprir necessidades simples, que antes não se percebia tanto, como os relacionamentos e as boas conversas entre amigos. O celular exemplifica bem esse contexto, ao mesmo tempo que aproxima as pessoas, separa-as. Entre tantas outras máquinas para necessidades simples. Parece que trocamos com as máquinas o viver e pelo sobreviver.

A tonalidade de humor e ironia, o emprego da síntese utilizada de uma forma a relacionar palavra e realidade, com senso de autocrítica, envolvem os versos do poema $O$ sobrevivente. Estruturado em versos livres, ele é escrito a partir dos aspectos da emoção, assim como é a vida, impregnada por momentos de emoção. O poeta diz que é se "Impossível compor um poema a essa altura da evolução da humanidade. Impossível escrever um poema - uma linha que seja - de verdadeira poesia". Ao mencionar tal expressão ele nos possibilita pensar que a sociedade se encontra perdida com a evolução tecnológica, levou-a a perder o contato com o mundo sensível e, que a escrita enquanto uma das partes expressivas do poema não consegue se quer ter expressividade de modo a fazer um poema de verdadeira poesia. É como se Drummond se perguntasse se ele faz poesia já que é impossível diante da evolução e afastamento do sensível.

Nesse sentido, se compreende o teor irônico apocalíptico lançado pelo poeta ao citar: "O último trovador morreu em 1914. Tinha um nome de que ninguém se lembra mais". Ao citar a data de 1914, o poeta, provavelmente está prevendo o acontecimento da I Guerra Mundial, e quando fala da morte do último trovador, deve estar se referindo ao poeta Augusto dos Anjos que faleceu em 12 de novembro de 1914. Drummond o cita pelo fato de ser um poeta bastante crítico quanto ao idealismo egocêntrico que se apresentava em sua época. Como o poema fala desse processo egocêntrico que o homem se tornou, Drummond utiliza a figura de Augusto dos Anjos como um representante crítico dessa realidade sobrevivida pelo sujeito que não mais vive, mas sobrevive.

Na terceira estrofe temos: "um sábio declarou ao jornal que ainda falta muito para atingirmos um nível razoável de cultura. Mas até lá, felizmente, estarei morto". O poeta vive nesse 
momento o seu tempo de pessimismo, pois acredita ser impossível ver a população vivenciar o seu nível de cultura. Porém, demonstra ironia ao dizer que felizmente até lá já estará morto, ou seja, da forma como o homem está sobrevivendo, ele nunca chegará ao nível razoável, pois vivencia sua mesquinhez diante do contexto tecnológico, no qual o homem vive numa dependência maquinaria, essa fazendo parte de forma exacerbada do cotidiano, afetando também os relacionamentos afetivos. Parece que o homem descrito pelo poeta se recusar a viver e aceita o que lhe impõe.

Ao comentar que os homens não melhoram e se matam como percevejos, há aí um sentimento de não preservação da própria raça, que o homem não ver o outro como ser humano, e que diante dessa luta, somente os percevejos heroicos renascem ou sobrevivem, isto é, só os fortes e resistentes viverão diante dessa grande realidade usurpadora da vida. Concluindo com: "Inabitável, o mundo é cada vez mais habitado. E se os olhos reaprendessem a chorar seria um segundo dilúvio. (Desconfio que escrevi um poema.)", o poeta ressalta com a frase "desconfio que escrevi um poema" que quer sobreviver apesar de toda essa realidade que corrói a alma humana, e que para mudar essa realidade é necessário uma nova poesia, pois é a poesia que traduz o belo e vida na sua melhor performance embora Drummond desconfie se o que faz seja poesia, pois até esta estaria ameaçada com a recusa do viver.

Insatisfação consigo mesmo, incômodo e "dificuldade de ser", a torção a que um "anjo torto" condenou o poeta, compensou-se com as tônicas da irrisão e do sarcasmo, levadas até o cerne da expressão lírica, colocada sob a suspeita da inautenticidade (NUNES, 1998, p. 263).

Ironismo e prosa tomam conta da poesia O sobrevivente de Drummond, revelando-se um poeta além do seu tempo, da realidade que vivenciava. Bosi (1975, p. 491-492) diz que Drummond é um "[...] hiato entre o parecer e o ser dos homens e dos fatos que acaba virando matéria privilegiada de humor. [...] negativo na medida em que se ensombra com os tons cinzentos da acídia, do desprezo e do tédio, que resulta na irrisão da existência". Bem presente está o negativismo, momentos cinzentos, desprezo e ódio nas linhas poéticas do poema supracitado, porém escrito com beleza, mestria, reflexão além do explícito, e isso só é possível se perceber a partir de um olhar filosófico e literário, visto que são essas duas perspectivas que por detrás das palavras o belo desnuda naquilo que está realmente presente no nosso cotidiano, a vida no mundo sensível.

No poema Explicação um eu lírico se apresenta, ocorre um processo de encenação, expressão do eu, quase que um retrato autobiográfico, culminado numa individualidade irônica. Para termos uma visão do poema, apresentamos:

Explicação

Meu verso é minha consolação.

Meu verso é minha cachaça. Todo mundo tem sua, cachaça.

Para beber, copo de cristal, canequinha de folha-de-flandres,

folha de taioba, pouco importa: tudo serve.

Para louvar a Deus como para aliviar o peito,

queixar o desprezo da morena, cantar minha vida e trabalhos

é que faço meu verso. E meu verso me agrada.

Meu verso me agrada sempre...

Ele às vezes tem o ar sem-vergonha de quem vai dar uma cambalhota

mas não é para o público, é para mim mesmo essa cambalhota.

Eu bem me entendo.

Não sou alegre. Sou até muito triste.

A culpa é da sombra das bananeiras de meu país, esta sombra mole, preguiçosa.

Há dias em que ando na rua de olhos baixos 
para que ninguém desconfie, ninguém perceba que passei a noite inteira chorando.

Estou no cinema vendo fita de Hoot Gibson, de repente ouço a voz de uma viola...

saio desanimado.

Ah, ser filho de fazendeiro!

A beira do São Francisco, do Paraíba ou de qualquer córrego vagabundo,

é sempre a mesma sen-si-bi-li-da-de.

E a gente viajando na pátria sente saudades da pátria.

Aquela casa de nove andares comerciais

é muito interessante.

A casa colonial da fazenda também era...

No elevador penso na roça,

na roça penso no elevador.

Quem me fez assim foi minha gente e minha terra

e eu gosto bem de ter nascido com essa tara.

Para mim, de todas as burrices a maior é suspirar pela Europa.

A Europa é uma cidade muito velha onde só fazem caso de dinheiro

e tem umas atrizes de pernas adjetivas que passam a perna na gente.

O francês, o italiano, o judeu falam uma língua de farrapos.

Aqui ao menos a gente sabe que tudo é uma canalha só,

lê o seu jornal, mete a língua no governo,

queixa-se da vida (a vida está tão cara)

Se meu verso não deu certo, foi seu ouvido que entortou.

Eu não disse ao senhor que não sou senão poeta? (ANDRADE, 2013, p. 74).

O título nos chama a atenção: "Explicação", o eu lírico vai comentar e explicar de que forma a sua vida é, como os fatos ocorrem e o que é mais significativo para ele. Atentamos que as duas primeiras estrofes são bem curtas, a primeira planejada em 4 (quatro) versos e a segunda em 3 (versos). O eu lírico nessas duas primeiras estrofes coloca de forma bem simples de que forma cada um se consola diante de alguma decepção ou faz para aliviá-la. Para Drummond, o que o consola e o alivia das dores é o seu verso, a sua poesia, por isso a expressão "meu verso é minha consolação" e "e meu verso me agrada".

É importante perceber que o eu lírico ao falar do consolo de outras pessoas cita instrumentos materiais "cachaça", "copo de cristal","canequinha de folha-de-flandres", "folha de taioba", "morena". Porém, para ele o verso que é um instrumento não material é que o mantém vivo. Percebe-se então que o Belo da vida e a sua felicidade não está apenas nos bens materiais. $O$ belo expressa o mundo sensível experienciado e vivido intensamente em suas nuances. Não importa se é a cachaça ou copo de cristal ou a olha de taioba ou o verso é o viver que nos possibilita essa experiência que pode ser sagrada perante algo.

A terceira estrofe se constrói em 21 (vinte e um) versos, vamos dizer que ocorre um desabafo melancólico que ainda corrói a alma do eu lírico. Toda essa tristeza que o acompanha tem um culpado: "a culpa é da sombra das bananeiras de meu país, esta sombra mole, preguiçosa". Esse fragmento remete há algo que tenha vivenciado ou que estava vivenciado e de repente fora arrancado de tal contexto. Há uma coisa que lhe deixa desanimado, o encontro entre o campo e a cidade, entre o desenvolvimento e o não desenvolvimento, entre a agitação e a calmaria, ao citar: "estou no cinema vendo fita de Hoot Gibson, de repente ouço a voz de uma viola....saio desanimado". O cinema nesse caso aparece como indício de modernidade, contrapondo-se ao som da viola, que o faz lembrar de sua vida na fazenda. Tal situação exige que ele reconheça ser um ser sensível: "é sempre a mesma sen-si-bi-li-da-de".

O eu lírico vive as contraposições em sua vida devido a brusca mudança, ou pela falta de uma identidade mais sólida, por isso a grande luta interna: "no elevador penso na roça, na roça 
penso no elevador". A quarta estrofe colabora para entender essa fragmentação identitária na qual o eu lírico se encontra, porque pela indicação deve ter raízes europeias: "para mim, de todas as burrices a maior é suspirar pela Europa", todavia critica essas raízes e por ter vivido nesse local. Exalta o local onde está vivendo, nesse caso o Brasil, e tipifica dizendo "aqui ao menos a gente sabe que tudo é uma canalha só, lê o seu jornal, mete a língua no governo, queixa-se da vida (a vida está tão cara) e no fim dá certo". Isso de Drummond de reconhecer identidade ganha em Benedito Nunes a ideia de brasilidade de se sentir impregnado pelo modo de ser brasileiro.

Na última estrofe, o eu lírico, joga a responsabilidade para o leitor, caso verso não tenha o atingido e ele não tenha compreendido, foram os seus ouvidos que distorceram o sentido do poema, e finaliza: "eu não disse ao senhor que não sou senão poeta?", ou seja, ele assume o seu papel de poeta que é a de manter a poesia viva, pois é ela que o mantém de pé, apesar desse grande vai e vem da vida, das transformações resultantes das mudanças temporais, físicas e geográficas.

Em relação a que o "verso" Ihe serve de consolo senão aos aspectos múltiplos da vida cotidiana? Evidentemente suas dores, seus devaneios, seus instantes são experiências suas, mas, constituem também facetas comuns ao gênero humano. Drummond procura caracterizar no espaço da vida moderna a solidão do homem, ao andar "na rua de olhos baixos" para que não se fragilize diante dos outros, revelando-lhes suas frustrações; presença da cultura de massa a partir de seus veículos de lazer e de informação; o apego aos materiais; e, sobretudo, o sentimento de ambivalência do que se compreende como cultura e civilização.

Os versos livres nesse poema, sem rima, sem estrutura representam a desconstrução do eu lírico, ou melhor, esse processo que ele vivencia diante do moderno e do antigo, do civilizatório e não civilizatório, do estar e do não estar. Vale destacar que a única coisa que o sustentou foi a poesia, porque para ele ela era a representação da vida, do novo, do desapego.

Por isso, Benedito Nunes ao unir o "Sobrevivente" e a "Explicação" afirma: "Para esse sobrevivente de uma outra época, o verso unido à prosa da vida, à matéria prosaica, impura, do cotidiano, ainda é 'consolação' e 'cachaça' e'[...] às vezes tem o ar sem-vergonha de quem vai dar uma cambalhota"' (NUNES, 1998, p. 263).

O terceiro poema em análise é Passagem da noite, esse está estruturado em duas estrofes, cada uma contendo 20 (vinte) versos. A quebra da passagem da primeira estrofe para a segunda é realizada pela conjunção adversativa "mas", que rompe com o conjunto de repetição de palavras, ou seja, as anáforas "é noite", repetida 9 (nove) vezes. Estabelecendo um processo contrastivo, de mudança, da primeira estrofe para a segunda.

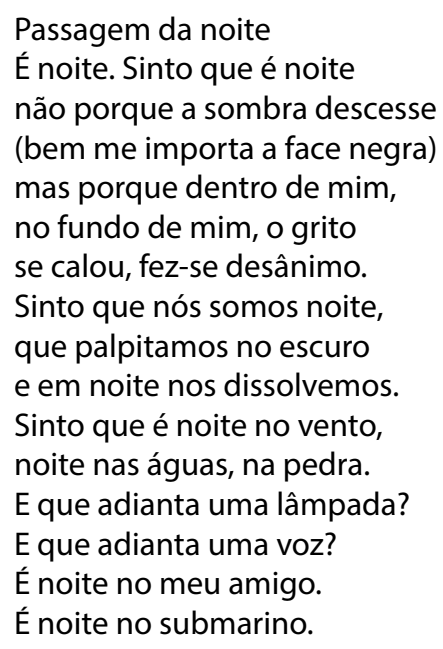




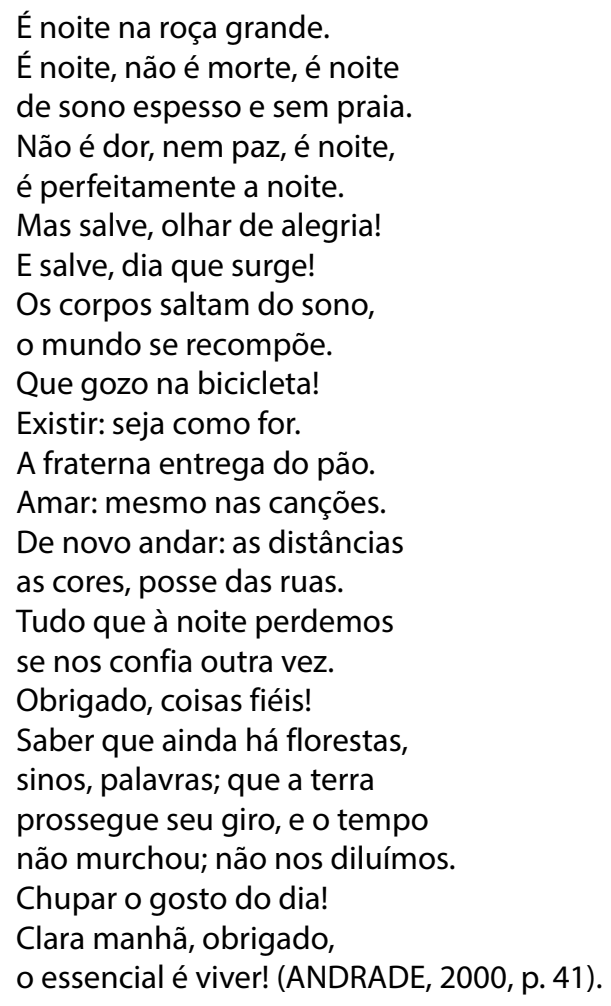

Percebemos na primeira estrofe que a palavra "noite" e a persistência em "é noite" toma conta desse primeiro momento do eu lírico. Esse momento de obscuridade é interno e pessoal: "mas porque dentro de mim, no fundo de mim, o grito se calou, fez-se desânimo". Posteriormente essa escuridão (noite) vai tomando conta dos outros que vivem ao seu redor: "Sinto que nós somos noite, que palpitamos no escuro e em noite nos dissolvemos". Tal atmosfera sombria parte do eu para o nós e depois vai se restaurando também nos elementos da natureza e no que está presente nela, como no vento, nas águas, na pedra, no submarino e na roça grande. $O$ eu lírico está vivenciado nesse primeiro momento uma situação sombria, melancólica, no qual projeta esse sentimento em tudo o que vê e no que está ao seu redor.

Porém, pensamos na noite, ela é passageira, por isso o título do poema Passagem da noite que remete esse momento temporal. $\mathrm{O}$ "efeito de aurora" que vem sendo produzido pode parecer paradoxal já que, nos versos imediatamente precedentes, existe um "pico de escuro", que significa a dominação das sombras pelo mundo a fora. Mas, este possível paradoxo se resolve quando pensamos no título Passagem da noite. Essa passagem indica algo circunstancial, em fase de transição, algo que não será permanente. Portanto, é de se esperar que a noite, embora tratando-se de um processo lento, chegue a um fim.

Como é passageira, o segundo momento vivenciado pelo eu lírico é de luz, introduzido como já citamos pela conjunção "mas" que tem grande peso semântico dentro desse contexto que comentaremos mais à frente. Vejamos como ocorre essa passagem e o que vivencia o eu lírico nos 4 (quatro) primeiros versos: "mas salve, olhar de alegria! E salve, dia que surge! Os corpos saltam do sono, o mundo se recompõe". A vida é recomposta pela alegria ao raiar do dia, com a chegada da luz, o corpo salta, vive, e tudo se recompõe.

Após esse momento, o eu lírico exalta todas as coisas existentes ao seu redor, pois ver luz em tudo e finaliza o segundo momento com os três versos: "chupar o gosto do dia! clara manhã, obrigado, o essencial é viver!". O verbo chupar está no sentido de aproveitar, aproveitar o máximo possível o dia proporcionado e que o mais importante de tudo é viver. 
Apontamos duas fases do ser humano nesse poema. A primeira fase que se refere à escuridão é o momento em que o ser humano se encontra em grandes dificuldades, perdido em meio ao obscuro ou se fecha para se proteger, pois não se sente seguro diante da realidade em que está inserido, por isso opta em viver na escuridão. Na segunda fase, o ser humano encontra soluções para os seus problemas e não consegue se prender neles. Quer aproveitar o dia e aquilo que está ao seu redor, pois o mais importante, o mais essencial é viver e não se entregar.

Soprado a Drummond pela voz daquela sua "musa filosófica" [...], esse motivo noturno recorrente, [...], realça aliado às imagens de dissolução, desgaste, perda - para não falarmos do frio e do sono em que também se investe - sobretudo nos poemas elegíacos, a partir de A Rosa do povo, o tema geral da finitude da condição humana, sujeita ao tempo e à morte (NUNES, 1998, p. 264).

Os três poemas de Drummond trazem à tona vários aspectos filosóficos e literários, traduzidos em questionamentos sobre a vida, sobre a realidade e sobre as circunstâncias delas, encontrando sempre soluções diante dos problemas apresentados. Percebemos que a arte poética se relacionando com a vida, que apesar de apresentar suas mais variadas facetas nebulosas, o belo constrói sua estrutura não só das palavras que compõe o poema, mas das ações cotidianas cuja poesia é solo de nascedouro do poema.

\section{Considerações finais}

A pesquisa em Benedito Nunes na compreensão sobre o belo, primeiramente mostrou o vínculo que há entre o filosófico e o literário na escrita desse filósofo brasileiro. Essa relação foi demonstrada pelos filósofos aqui apresentados: Platão, Aristóteles e Heidegger e no campo da literatura com Carlos Drummond. A poesia está para a filosofia e esta para aquela como duas mãos que se tocam mutuamente. Essa dialética conduz-nos a um pensamento poético e a uma poesia pensante. Esse movimento ininterrupto precisa ser re/descoberto para permitir compreender a poesia como poiesis assim como a filosofia tem se esforçado para ser. Benedito Nunes nos ensina através de seus textos, particularmente com o Crivo de papel, estabelecer a relação da filosofia com a poesia ou do pensamento com a poesia de modo que habitemos a poiesis como lugar onde se emerge o belo.

Assim, chegamos a segunda compreensão objeto principal deste artigo, a compreensão do que é o belo. Pela exposição que foi feita chegamos à conclusão que o Belo é o Sensível ${ }^{2}$, o ser, que se expressa nas realidades sensíveis percebidas pelo percebedor que mantem com ele uma relação de reciprocidade. A experiência sensível do "ser-no-mundo", na ordem do que é vivido e não apenas do que é pensado, pois a experiência perceptiva do corpo pode ser considerada pré-objetiva. Isso se dá pela relação eu, o outro e as coisas em estado pré-reflexivo, admitindo uma expressão vital primordial, que desencadeia numa relação que a linguagem torna seu nascedouro.

O belo na perspectiva filosófica de Benedito Nunes não consegue ser descrito em sua totalidade pelas palavras, pois são aproximativas. O belo é vivência das realidades sensíveis como descritas pelos poemas de Drummond. Fala-se de uma realidade que se traduz nas pala-

\footnotetext{
${ }^{2}$ Não confundir Sensível com aspectos subjetivos, mas na esteira de Heidegger como algo ontológico voltado para a relação intrínseca que se estabelece entre os entes.
} 
vras, mas que ao mesmo tempo que desvela tal realidade ele se vela novamente. Nem mesmo a interpretação consegue cumprir seu papel de trazer plena luz às realidades expressas.

A partir da visão de Benedito Nunes entendemos que o belo se desenvolve na linguagem poética e que ela se traduz e está relacionada com a vida, com o ser humano, com as coisas, e com tudo aquilo que se faz presente ao nosso redor. As três poesias selecionadas: $O$ sobrevivente, Explicação e Passagem da noite apresentam em toda a sua extensão o belo.

Portanto, ao chegarmos ao fim textual deste artigo procuramos responder ao problema desta pesquisa, porém já vislumbramos um leque de possibilidades de investigação que não se reduz a este artigo. Perguntas como: por que o belo é expressão do ser? Que ser? Por que o viver é expressão autêntica do belo alcançado somente pela percepção? Para respondê-las muito pode contribuir Benedito Nunes com sua filosofia. E como a poesia e a filosofia precisam serem sempre revisitadas para compreendermos o belo que habitamos e que nos habita.

\section{Referências}

ANDRADE, Carlos Drummond de. A rosa do povo. 21a ed. Rio de Janeiro, São Paulo: Record, 2000. ANDRADE, Carlos Drummond de. Alguma poesia. São Paulo: Companhia das Letras, 2013. BOSI, Alfredo. Histórica concisa da literatura brasileira. 2a ed. São Paulo: Cultrix, 1975.

GREUEL, Marcelo da Veiga. Da "teoria do belo" a "estetica dos sentidos": Reflexões sobre Platão e Friedrich Schiller. Anuário de Literatura 2, pp. 147-155, 1994.

HEIDEGGER, Martin. "... poeticamente o homem habita.... In: HEIDEGGER, Martin. Ensaios e conferências. $2^{\mathrm{a}}$ ed. Rio de Janeiro: Vozes, 2002c, p. 165-183.

MAGALHÃES, Antonio. Partilhas do saber: diálogos entre filosofia e literatura. Revista Páginas de Filosofia, v.1, n.2, p. 47-59, jul/dez 2009.

MEDEIROS NUNES, Yamille Fragoso de. A obra de arte na filosofia de Martin Heidegger. Trabalho de Conclusão de Curso. Universidade Estadual de Paraíba, Centro de Educação, 2014.

NUNES, Benedito. Crivo de papel. 2a ed. Editora Ática: São Paulo, 1998.

NUNES, Benedito. Heidegger e a poesia. Natureza Humana 2(1):103-127, 2000.

SANTOS, Natália Gonçalves de Souza. Pólos de oposição na poesia drummondiana: uma leitura do poema "passagem da noite". Revista Travessias, v. 1, n. 1, 2007.

VIANA, Carlos Augusto (2017). Presença do cotidiano e crítica social em Carlos Drummond de Andrade. Disponível em: <file:///D:/TCC\%20Michele/Boa\%20para\%20a\%20an\%C3\%A1 lise $\% 20$ e\%20para\%20pega\%20parte\%20te\%C3\%B3rica\%20\%200\%20Marrare.html>. Acesso em: 18. maio. 2019.

\section{Sobre os autores}

José Roberto Gomes

Doutor em Filosofia pela Universidade Federal da Paraíba (2019). Mestre em Filosofia pela Universidade Federal da Paraíba (2016). Especialista em Psicopedagogia (2013). Graduado em Filosofia (2011). Bacharel em Teologia (2012). Formação em fundamentos da Psicanálise (2021). Professor efetivo da Universidade 
Federal do Amazonas - Campus Humaitá. Atua na área de Filosofia e Legislação do Ensino Básico. Pesquisa a Filosofia de Merleau-Ponty. Participa do grupo de pesquisa da Filosofia da Percepção (UFPB) e do grupo de estudos e pesquisa em Filosofia Arandu. Leciona disciplinas de Filosofia e Legislação do Ensino Básico.

Michele Menezes da Silva

Graduada em Letras pela Universidade Federal do Amazonas. Participa do grupo de estudos e pesquisa em Filosofia Arandu.

Recebido em: 20.04.2021

Received: 20.04.2021.

Aprovado em: 02.08.2021

Approved: 02.08.2021. 